\title{
O estudo do ritmo climático e sua influência nos incêndios residenciais urbanos em Santa Maria - RS
}

\author{
Urban residential fires in the summers of the years 2011, 2012 and 2013 in Santa \\ Maria - RS
}

\author{
André Ademir Weber ${ }^{1}$, Cássio Arthur Wollfman², Amanda Comassetto Iensse ${ }^{3}$ \\ ${ }^{1}$ Graduando em Geografia Bacherelado da UFSM , Santa Maria, Brasil \\ ${ }^{2}$ Professor, Doutor adjunto do departamento de geociências da UFSM, Santa Maria, Brasil \\ ${ }^{3}$ Graduanda em Geografia Bacherelado da UFSM , Santa Maria, Brasil
}

\begin{abstract}
Resumo
Nos últimos anos pode-se notar um aumento significativo no número de incêndios residenciais, pelos mais determinados motivos, porém, quando os associamos a sucessão dos diferentes tipos de tempos atmosféricos abrese um novo leque de fatores que podem desencadear esse tipo de sinistro, principalmente quando é associado ao crescimento vigoroso do consumo residencial de eletricidade da população urbana brasileira nos últimos 20 anos, conforme pesquisa divulgada pela Empresa Brasileira de Pesquisa Energética (EPE, 2006). Desta forma, objetiva-se analisar a influência climática dos incêndios ocorridos nos verões dos anos 2011, 2012 e 2013 utilizando a técnica da análise rítmica. Optou-se em realizar primeiramente o levantamento dos verões por se tratar, teoricamente, do período do ano mais susceptível a esse tipo de sinistro. Cabe ressaltar que os dados foram recolhidos junto ao acervo jornalístico do jornal "O Razão" localizado na Cidade. Os dados referentes aos tipos de tempo foram coletados junto à estação climatológica da Universidade Federal de Santa Maria. Durante o período de tempo analisado foi registrado um total de 28 incêndios, sendo 19 incêndios residenciais, assim, constatou-se a ligação entre os incêndios residenciais urbanos e os fatores climáticos, principalmente sob o domínio das Massas Tropicais continentais, onde $52,6 \%$ dos casos estavam ligados a esse domínio, que tem por característica apresentar um tempo quente e seco.
\end{abstract}

Palavras-chave: . Analise Rítmica.Climatologia Geográfica . Incêndio Residencial

\begin{abstract}
In the last years can be noted a significative increase in the number of urban residential fires, by various reasons, but, when associated with succession of different kinds of weather, opens a new range of factors that can trigger this type of accident, especially when it is associated with the vigorous increase in residential consumption of eletrical energy in the last 20 years, as search of Brazilian Energy Research Company (EPE, 2006). So, the objective is to analyze the climatic influence in the occurring fires in the summers of the years 2011, 2012 and 2013 using the technique of rhythm analysis. it was decided at first to survey summers by treating, theoretically, the time of year most susceptible to this type of accident. Note that the data were collected from the journalistic collection of "A Razão" journal, situated in the town. The data relating to weather types were collected from the climatological station of the Federal University of Santa Maria. During the period of time examined was recorded a total of 28 fires, being 19 residential fires, so, was observed the connection between urban residential fires and the climatic factors. Especially under domain of Tropical continental masses, in which $52.6 \%$ of the cases were related to that domain, which has by characteristic has a hot and dry weather.
\end{abstract}

Keywords: . Rhythm Analysis. Geographic Climatology .Residential fires 


\section{Introdução}

A Geografia em sua gênese tem a função de estudar a relação entre a sociedade e a natureza, relações que por muitas vezes podem ser onerosas ao convívio entre essas duas pontas. Nesse sentido, cabe então a Ciência Geográfica a interligação e a resolução dos problemas causados ora pela sociedade, ora pelas manifestações dos fenômenos naturais.

Nos últimos anos pode-se notar um aumento significativo no número de incêndios residenciais, pelos mais determinados motivos, porém, quando os associamos a sucessão dos diferentes tipos de tempos atmosféricos abre-se um novo leque de fatores que podem desencadear esse tipo de sinistro, principalmente quando é associado ao crescimento vigoroso do consumo residencial de eletricidade da população urbana brasileira nos últimos 20 anos, conforme pesquisa divulgada pela Empresa Brasileira de Pesquisa Energética (EPE, 2006). Dados do Balanço Energético Nacional (BEN), divulgados pela mesma empresa, mostram que o consumo residencial total no país cresceu 89,5\% entre 1989 e 2005.

Os incêndios residenciais constituem um evento catastrófico, infelizmente, constantemente presente em nosso cotidiano, afetando todas as classes da sociedade, os estudos acerca do comportamento espacial e levando em conta fatores climáticos e de consumo de energia ainda são escassos mediante tamanha importância da prevenção deste tipo de catástrofe.

Deste modo, busca-se uma aproximação dos estudos climáticos a fatos de relevante importância ao planejamento e a prevenção de sinistros, com o objetivo de disponibilizar o conhecimento produzido pela Univer- sidade a população em geral.

O presente trabalho tem, então, como indicador espacial o município de Santa Maria - RS, mais precisamente a sua área urbana, localizada no centro geográfico do estado do Rio Grande do Sul, a 29 $41^{\prime}$ 25' de latitude

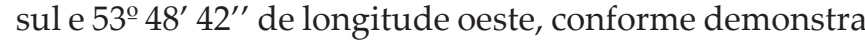
a figura 01. Totalizando uma população total, segundo o IBGE (2010), de 261.031 habitantes, sendo que aproximadamente $95 \%$ de sua população residem na área urbana, destacando-se como polo regional, caracterizada pela prestação de serviços educacionais, de saúde, comercial e militar.

Segundo Sartori (2003) e Costa (2009) o município ocupa posição privilegiada para o estudo climático, pois tem condições de refletir o comportamento da circulação atmosférica regional, ficando continuamente submetida aos efeitos dos Sistemas Atmosféricos Extratropicais (Massas e Frentes Polares) de maior participação e dos Sistemas Intertropicais (Massas Tropicais Marítimas e Continentais) que se alteram na circulação atmosférica secundária do estado, ao longo do ano.

Mediante as considerações mencionadas anteriormente a respeito do suposto aumento do número de incêndios na área urbana de Santa Maria, e os danos dos mesmos à população, foram estabelecidos como objetivo geral da pesquisa analisar, através da técnica de Análise Rítmica, os incêndios residenciais urbanos da cidade de Santa Maria - RS em relação aos diferentes tipos de tempo nos verões de 2011, 2012 e 2013. Como objetivos específicos pretende-se coletar e analisar a variabilidade diária e mensal de dados de temperatura do ar, umidade relativa do ar, precipitação pluviométrica, pressão atmosférica, direção do vento, referentes ao

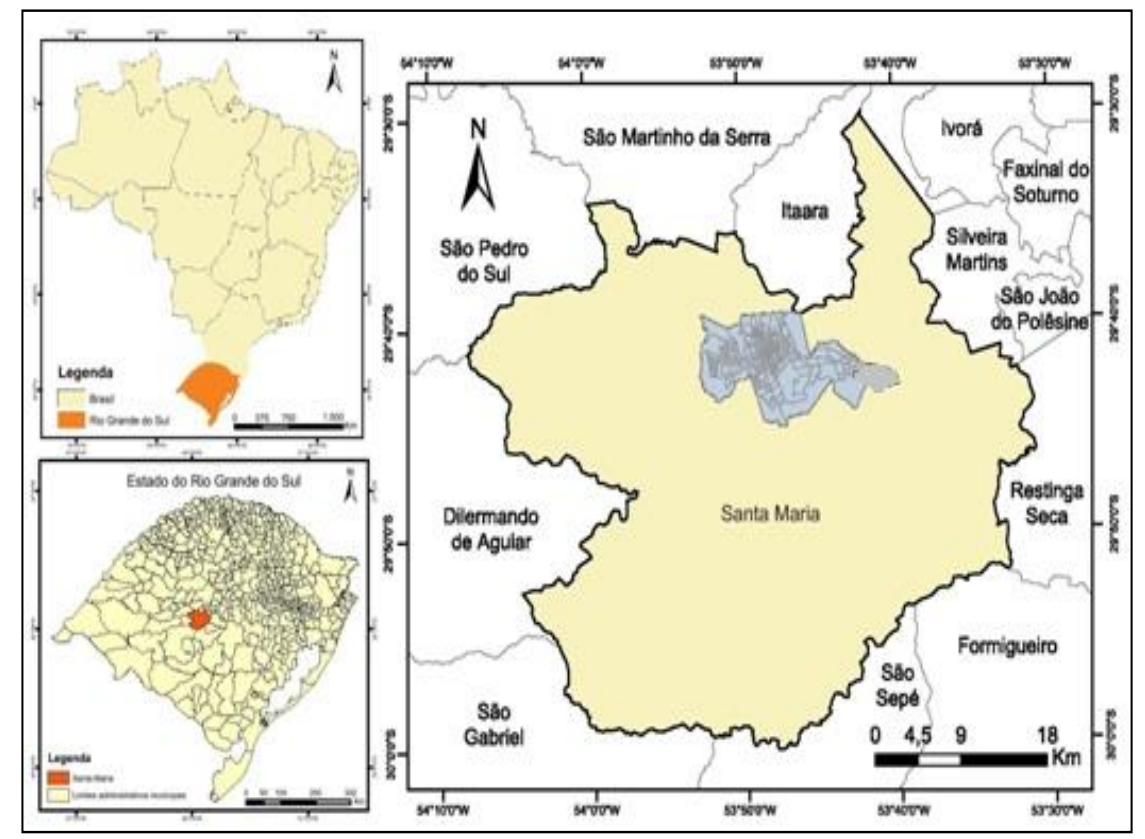

Figura 01: Localização do Município de Santa Maria - RS

Org.: Weber, A. A. 2013 
período de 2011, 2012 e 2013; relacionar a sucessão dos diferentes tipos de tempo com a ocorrência de incêndios residenciais na área urbana de Santa Maria - RS; assim como localizar e mapear os incêndios residenciais em Santa Maria - RS.

\section{Materiais e Métodos}

A interação entre os elementos atmosféricos tais como temperatura, pressão, umidade do ar, e a superfície (fatores geográficos) permitem, por um lado, a identificação e análise de unidades climáticas diferenciadas e, por outro, o jogo de influências recíprocas entre a atmosfera e a sociedade (Mendonça, 2002), desta forma se buscará analisar um fenômeno climático e sua influência sobre desastres que afligem a sociedade.

Visando uma clara explicitação dos passos desta pesquisa, bem como das técnicas empregadas, elaborou-se um roteiro metodológico (figura 02), distribuído em três fases.

A elaboração desta primeira parte está vinculada à fundamentação teórica, ou seja, a formação de uma base teórico-metodológica cujos referenciais possibilitem embasamentos às ideias propostas, ainda nesta primeira fase, elabora-se a problematização do tema de estudo, bem como a estruturação da pesquisa.

A segunda fase está ligada a coleta e análise dos dados referentes ao número de incêndios e condições atmosféricas (a ser investigada através da utilização da técnica de Análise Rítmica), dados estes coletados junto aos jornais da cidade e da estação climatológica da Universidade Federal de Santa Maria, respectivamente.

A partir disso, foram coletados dados climáticos diários, mensais e anuais da Estação Climatológica da Universidade Federal de Santa Maria, pertencente à rede oficial do Instituto Nacional de Meteorologia (INMET), referentes aos verões dos anos de 2011, 2012 e 2013. Os dados coletados na Estação Climatológica serão relacionados ao número de incêndios do período em questão.

A partir da coleta dos dados, foram construídos gráficos referentes à temperatura do ar, umidade relativa do ar, precipitação pluviométrica e pressão atmosférica, com auxilio do aplicativo Microsoft Excel 2007, assim como do software Ritmo-analise para a elaboração dos gráficos de análise rítmica, onde foram estabelecidos, a partir dos trabalhos de Sartori (1993) e Wollmann (2009), a predominância dos sistemas atmosféricos dominantes assim como dos diferentes tipos de tempo. Para melhor visualização dos sistemas atmosféricos dominantes foram utilizadas cartas sinóticas e imagens de satélites diárias coletadas junto ao site da Marinha do Brasil.

Na segunda fase, ainda, com o auxílio do software arcgis 9.3, foi elaborado um mapa com a distribuição espacial dos incêndios ocorridos no recorte temporal em questão. Já na terceira fase da ação revelará a influência das condições climáticas sobre os casos de incêndio na cidade.

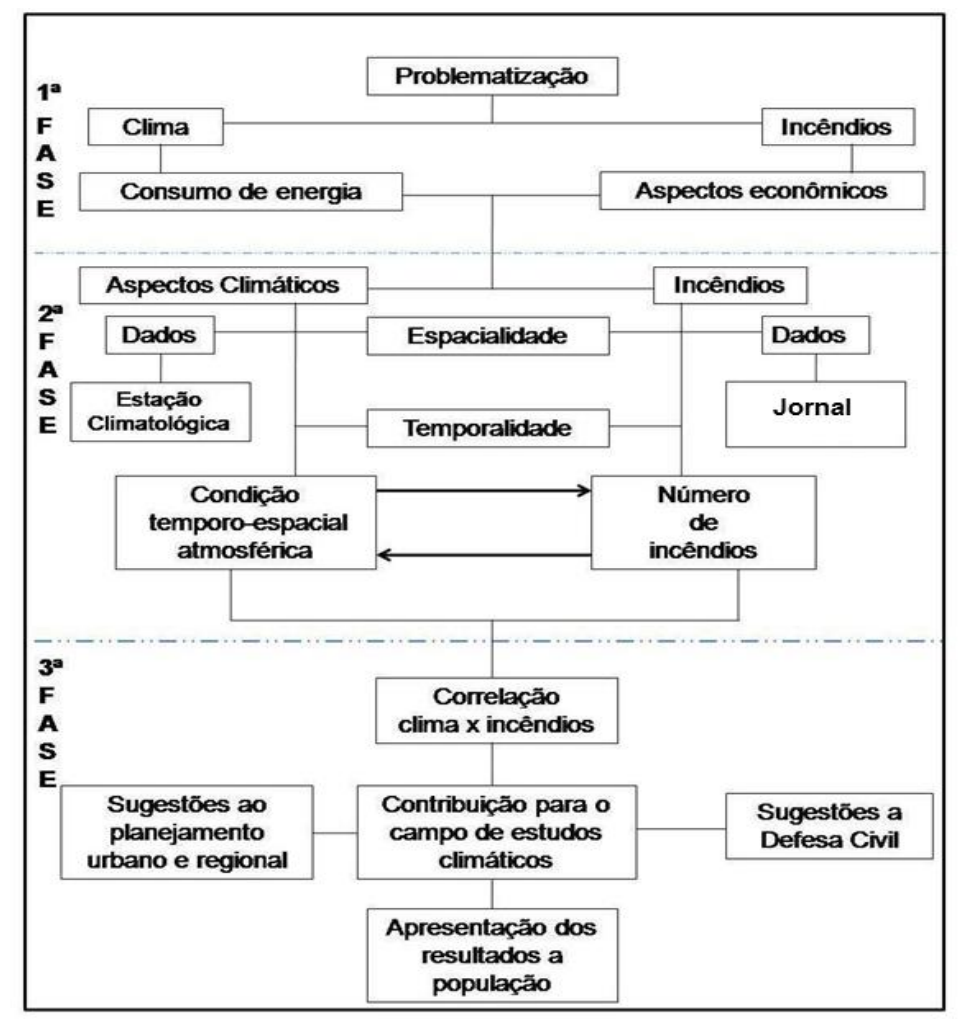

Figura 02: Roteiro Metodológico

Org.: Weber, A. A., 2013 


\section{Fundamentação Teórica}

\subsection{Circulação da Atmosfera}

Para Ayoade (1991), a circulação atmosférica pode ser classificada em três escalas de abrangência, considerando escala, área e tempo. A primeira escala corresponde à circulação primária ou zonal, determinada pela circulação geral da atmosfera e pelos padrões de vento e pressão, responsáveis pelos diferentes tipos de clima no mundo. A segunda escala está inserida na circulação zonal, como a atuação dos centros de ação positivos, já a terceira escala ou local, está inserida na circulação regional e as respostas locais as sucessões de tempo.

No aspecto das escalas propostas por Ayoade (1991), será feita uma breve consideração acerca da circulação secundária na região sul do Brasil, nesse aspecto destacam-se estudos de Monteiro (1963; 1990), Nimer (1989), Sartori (1980; 1981; 2000; 2003) e Wollmann (2008, 2009, 2010), que permitiram uma melhor compreensão da dinâmica e circulação dos mecanismos atmosféricos de atuação regional.

Os centros de ação formadores dos sistemas atmosféricos que definem diretamente o quadro climático da região Sul do Brasil são três: o Anticiclone Migratório Polar, responsável pelas Massas Polares Atlânticas e Pacíficas; o Anticiclone Semifixo do Atlântico Sul, formador da Massa Tropical Atlântica e a Baixa do Chaco que origina a Massa Tropical Continental.

As Massas Polares são oriundas do Anticiclone Polar Móvel, originário das baixas pressões polares e por fluxo de ventos divergente se desloca as altas subtropicais, ao se encontra com a Cordilheira dos Andes, ao sul do continente, bifurca-se formando a Massa Polar Pacífica que ruma a oeste da América do Sul, e a Massa Polar Atlântica rumando a leste do continente, com forte atuação sobre o Brasil Meridional, durante o ano inteiro, Nimer (1989) destaca que em decorrência de sua baixa temperatura, chuvas mais ou menos abundantes assinalam sua passagem, que estão associadas às Frentes Polares.

Em uma situação de domínio das condições atmosféricas pela Massa Polar Atlântica, temos a estabilidade do tempo atmosférico com céu totalmente limpo o que facilita a entrada de radiação solar na superfície e consequente aquecimento do ar (Sartori, 1981).

No que se refere à atuação da Massa Tropical Atlântica, a sua atuação é direta e indireta durante o ano inteiro, é originária do anticiclone do Atlântico Sul, seus efeitos variam conforme a época do ano, Monteiro (1963) enfatiza que no verão, a Massa torna-se inferiormente instável pelo aquecimento basal que sofre ao contato com o continente que é agravado pelo efeito orográfico do sistema atlântico, durante o inverno, o resfriamento basal aumenta a estabilidade superior contribuindo para a ocorrência de tempo bom.

Outra massa com atuação intensa durante o verão é a Massa Tropical Continental, Nimer (1989) admite que essa massa adquira maior importância durante o verão, dos fins da primavera ao inicio do outono. Sua zona de origem se localiza a leste dos Andes e ao sul do Trópico de Capricórnio, uma zona baixa quente e árida, essa massa é oriunda da frontólise da Massa Polar Pacífica que ao transpor a Cordilheira, sofre o efeito de dissecação adiabática, o autor ainda aponta que a massa é responsável por tempo quente e seco.

\subsection{Análise Rítmica em Climatologia}

Os estudos acerca da análise rítmica em Climatologia tem sua base nos trabalhos de Monteiro, porém ao se analisar a região Sul surge, primeiramente, os trabalhos de Sartori (1980) e posteriormente Wollmann (2008; 2009), onde os autores definem os padrões e caracterização dos tipos de tempo da região Sul e, principalmente, no estado do Rio Grande do Sul, assim se utilizará como base bibliográfica e metodológica os trabalhos desses autores.

O conceito de "ritmo", expressão da sucessão dos estados atmosféricos, conduz, implicitamente, ao conceito de "habitual", pois há variações e desvios que geram diferentes graus de distorções até atingir padrões "extremos" (Monteiro, 1971). O autor coloca, também, que o que se entende por ano seco e anos chuvosos conduz a uma lenta tarefa de revisão, até que se possa optar por uma norma mais conveniente aos nossos propósitos. A primeira aproximação válida para o conceito de ritmo seria aquela das variações anuais percebidas através das variações mensais dos elementos climáticos.

Wollmann (2009) aponta que a análise do ritmo e sucessão do tempo permite a realização da frequência sazonal de participação dos sistemas atmosféricos sobre uma determinada região, que pode ser uma das formas de se classificar o seu clima. Nesse sentido Monteiro (1964) assinala que a necessidade de caracterizar o ritmo climático exige decomposição cronológica já que os estados atmosféricos, em continua sucessão se produzem em escalas bem menores.

Monteiro (op. cit.) valida à conclusão que o ritmo climático só poderá ser compreendido através da representação concomitante dos elementos fundamentais do clima em unidades de tempo cronológico, pelo menos diárias, compatíveis com a representação da circulação atmosférica regional, geradora dos estados atmosféricos que se sucedem e constituem o fundamento do ritmo.

\subsection{Sucessão habitual dos tipos de tempo no Rio Grande do Sul}

Considerando a abordagem consagrada pela Climatologia Geográfica, os estudos sobre a circulação atmosférica e os tipos de tempo no Rio Grande do Sul restringem-se aos realizados por Sartori (1980; 1981; 2000; 2003). Posteriormente destacam-se os trabalhos de Wollmann $(2008 ; 2009 ; 2010)$. Neste trabalho serão utilizados a luzes destes dois autores no memento de 
definir os tipos de tempo predominantes na área a ser estudada.

A sequência de tipos de tempo, de forma cíclica mais ou menos prevista, constitui o que Sorre (1951, apud Sartori, 2003) definiu como sucessão habitual dos tipos de tempo e que é própria de determinado lugar.

Segundo Sartori (2003), a sucessão habitual dos tipos de tempo se faz através de ciclos com quatro fases bem características e de duração variável. Dessa maneira a autora define quinze principais tipos de tempo, que foram identificados e reunidos em três famílias, de acordo com sua gênese: Tempos Anticiclonais Polares, Tempos associados a Sistemas Intertropicais e Tempos associados às Correntes Perturbadas.

Ao caracterizar os verões sul-rio-grandenses Sartori constatou que a participação maior é da MPV que, em média, domina em mais de $45 \%$ dos dias da estação. A FPA aparece em segundo lugar no número de dias sob seu domínio, totalizando mais de $20 \%$ dos dias de verão, embora em sua passagem nem sempre se registrem precipitações. A MPA típica tem participação em cerca de $20 \%$ dos dias, dominando a região por apenas um ou dois dias (quando diminuem as temperaturas), entre os Sistemas Intertropicais, a MTA, incluindo sua interiorização (MTAC), e a MTC são as que têm maior participação na circulação atmosférica regional, dominando em cerca de $5 \%$ dos dias cada uma. Além das massas de ar de origem tropical, há atuação das Instabilidades Tropicais ou de Noroeste e de Calhas Induzidas em cerca de $7 \%$ e $5 \%$ dos dias, respectivamente, associadas às fases pré-frontais e independentes da massa de ar dominante.

Ainda sobre verão Wollmann (2009) classifica os verões em três tipos: habitual, mais chuvoso e menos chuvoso. $\mathrm{O}$ autor classifica os verões, também, a partir da sucessão habitual dos tipos de tempo e sua predominância. De acordo com Wollmann (2009), no verão habitual, a Massa Polar Velha dominou a maior parte do tempo, à exceção de dezembro. Entre as correntes perturbadas, as de maior frequência no Estado são as Frentes Polares. No verão mais chuvoso observou-se também a maior atuação dos sistemas de origem extratropical que deram à estação elevados totais pluviométricos. No verão menos chuvoso foram as massas de ar de origem polares descaracterizadas que dominaram praticamente durante toda a estação.

Wollmann (op. Cit.) ainda destaca que é possível classificar os verões segundo a caracterização do ano em habitual, mais ou menos chuvoso. O autor destaca que em relação aos anos-padrões menos chuvosos, os totais por estação devem ficar abaixo de $350 \mathrm{~mm}$, sendo registrados de forma homogênea. Já para os anos-padrões mais chuvosos, os totais sazonais de chuva devem permanecer, de forma homogênea entre as quatro estações, acima de $450 \mathrm{~mm}$.

\section{Resultados}

Optou-se em realizar primeiramente o levantamento dos verões por se tratar, teoricamente, do período do ano mais susceptível a esse tipo de sinistro. Cabe ressaltar que os dados foram recolhidos junto ao acervo jornalístico do jornal “O Razão" localizado na Cidade de Santa Maria/ RS. Foram considerados os meses em que se iniciam e terminam os verões. Então os verões se iniciam, geralmente, no dia 21 de dezembro, porém foram considerados os incêndios que aconteceram anteriormente a essa data, assim como os incêndios posteriores as datas dos dias 23 de março dos respectivos anos, posteriores ao fim do verão. Ainda se destaca a dificuldade de se encontrar a causa dos incêndios devido aos dados serem levantados junto a um acervo jornalístico, onde a preocupação maior é em se registrar a notícia e, por muitas vezes, a causa do incêndio é deixada de lado. Ressalta-se, ainda, que os levantamentos dos dados de incêndios foram feitos no jornal devido à falta de registros junto ao corpo de bombeiros, assim como junto a polícia civil.

\subsection{Incêndios}

Primeiramente foram levantados todos os tipos de incêndios urbanos: residenciais, em áreas industriais, comerciais, assim como campos e florestas, foram contabilizados um total de 29 incêndios entre os verões de 2011, 2012 e 2013, destes, foram apurados 19 incêndios que se configuraram como incêndios residenciais.

No verão 2010/2011 foram registrados um total de 4 incêndios sendo todos no meses de fevereiro e março, sendo um em uma área de campo no bairro Alto da Boa Vista e outra em um salão comunitário na Cohab Nova Santa Marta. Os outros dois incêndios foram em áreas residenciais, sendo um com ocupação mista entre residencial e comercial, desta forma ocorreram dois incêndios residenciais, conforme demonstra a tabela 01.

Tabela 01: Incêndios no verão de 2010/2011 na cidade de Santa Maria/RS.

\begin{tabular}{ccccc}
\hline Data & Local & Danos & Causa & Tipo de ocupação \\
\hline $02 / 02 / 2011$ & $\begin{array}{c}\text { Bairro Tancredo } \\
\text { Neves }\end{array}$ & Parcial & Desconhecida & Residencial \\
\hline 23/03/2011 & Centro & Parcial & Desconhecida & Comercial/Residencial \\
\hline
\end{tabular}

Fonte: Jornal "A Razão"

Org.: Weber, A. A., 2013 
Tabela 02: Incêndios no verão 2011/2012 na cidade de Santa Maria - RS

\begin{tabular}{ccccc}
\hline Data & Local & Danos & Causa & Tipo de ocupação \\
\hline $02 / 12 / 2011$ & Bairro Salgado Filho & Total & Desconhecida & Residencial \\
\hline $17 / 12 / 2011$ & Bairro Boi Morto & Total & Desconhecida & Residencial \\
\hline $17 / 12 / 2011$ & Bairro Rosário & Total & Curto-Circuito & Residencial \\
\hline 26/12/2011 & Linha Velha Da Fronteira & Total de Três Casas & Criminoso & Residencial \\
\hline 30/12/2011 & Itararé & Total & Desconhecida & Residencial \\
\hline 31/12/2011 & Medianeira & Total & Curto-circuito & Residencial \\
\hline 19/01/2012 & Alto da Boa Vista & Total de Duas Casas & Desconhecida & Residencial \\
\hline 26/01/2012 & Bairro Perpétuo Socorro & Total & Desconhecida & Residencial \\
\hline 07/02/2012 & Parque Pinheiro Machado & Parcial & Desconhecida & Residencial \\
\hline 24/02/2012 & Centro & Parcial & Desconhecida & Residencial \\
\hline 06/03/2012 & Bairro Rosário & Total & Desconhecida & Residencial \\
\hline 19/03/2012 & Vila Schirmer & Total de Duas Casas & Desconhecida & Residencial \\
\hline 24/03/2012 & Centro & Parcial & Curto-Circuito & Residencial \\
\hline 29/03/2012 & Parque Pinheiro Machado & Total & Desconhecida & Residencial \\
\hline
\end{tabular}

Fonte: Jornal "A Razão"

Org.: Weber, A. A., 2013

No verão 2011/2012 foram apontados 21 incêndios na área urbana de Santa Maria, em todos os meses do verão, dentre eles 14 foram em áreas residenciais nos mais variados bairros da cidade. Ainda registraram-se incêndios em áreas de campo (4), comercial (1), industrial (1) e uma escola. No mês de dezembro foram anotados 8 incêndios, enquanto no mês de janeiro foram citados 6 incêndios, no mês de fevereiro dois e em março 5 incêndios, conforme indica a tabela 02 .

No verão 2012/2013 foram anotados apenas três incêndios, nos meses de dezembro, janeiro e fevereiro, todos eles residenciais. Os incêndios ocorreram nos bairros
Centro, Passo D'areia e Parque Pinheiro Machado. O que chama atenção é que dos três incêndios dois foram com perda total, conforme demonwwwwstra a tabela 3.

A partir dos dados levantados elaborou-se um mapa com a distribuição espacial dos incêndios ocorridos nos respectivos verões (figura 03), verificou-se que a grande parte dos incêndios ocorreu longe do centro da cidade, principalmente em áreas periféricas, onde as condições econômicas e a rede de distribuição de energia elétrica são mais precárias, onde com o aumento do consumo de eletrodomésticos nos últimos anos pode ter gerado uma sobrecarga no sistema elétrico.

Tabela 03: Incêndios no verão 2012/2013

\begin{tabular}{ccccc}
\hline Data & Local & Danos & Causa & Tipo de ocupação \\
\hline $28 / 12 / 2012$ & Centro & Parciais & Curto- Circuito & Residencial \\
\hline $24 / 01 / 2013$ & $\begin{array}{c}\text { Parque Pinheiro } \\
\text { Machado }\end{array}$ & Total & Desconhecido & Residencial \\
\hline $03 / 02 / 2013$ & Passo D'areia & Total & Acidental & Residencial \\
\hline
\end{tabular}




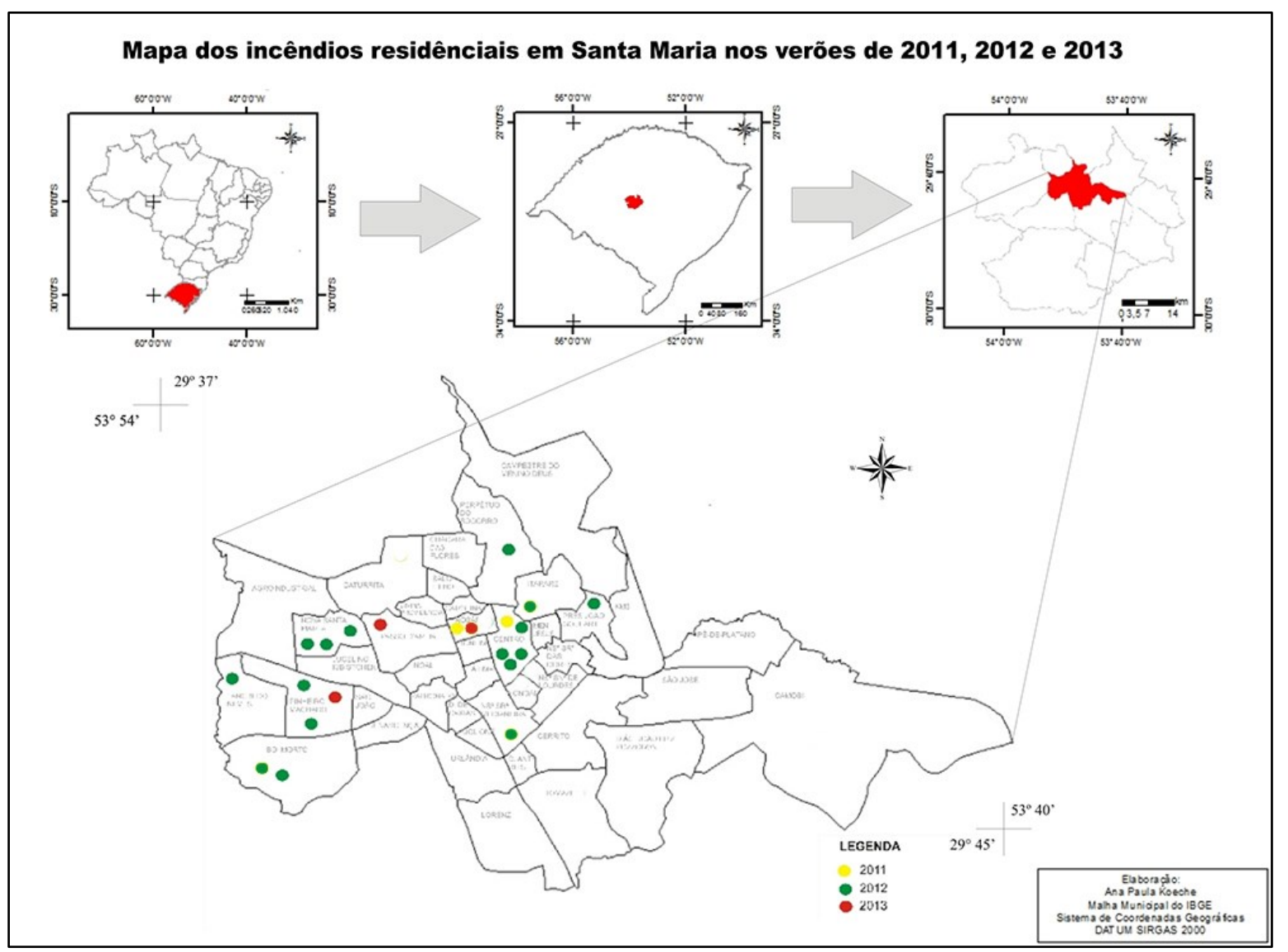

Figura 03: Localização dos incêndios residenciais em Santa Maria nos Verões de 2011, 2012 e 2013.

\subsection{Sistemas atmosféricos}

Dentre os verões analisados utilizou-se a classificação de Wollmann (2009) que classifica os verões em habitual, mais ou menos chuvoso conforme o total de precipitação da referida estação. O autor destaca que em relação aos anos-padrões menos chuvosos, os totais por estação devem ficar abaixo de $350 \mathrm{~mm}$, sendo registrados de forma homogênea. Já para os anos-padrões mais chuvosos, os totais sazonais de chuva devem permanecer, de forma homogênea entre as quatro estações, acima de $450 \mathrm{~mm}$.

No caso do verão de 2012/2013 constatou-se uma precipitação de $560,4 \mathrm{~mm}$, sendo assim considera-se um verão mais chuvoso, já nos verões de 2010/2011 e 2011/2012 constataram-se totais pluviométricos inferiores a $350 \mathrm{~mm}$, consideram-se, então, verões menos chuvosos, a tabela 07 exemplifica a situação.

A partir da análise dos dados coletados junto a Estação Climatológica da Universidade Federal de Santa Maria e com ajuda de imagens de satélite foi possível identificar os sistemas atmosféricos mais atuantes durante o período das referidas estações do ano.

Deste modo constatou-se que no verão 2010/2011 houve um predomínio das massas tropicais continentais (50,5\%), posteriormente Massas Polares Atlânticas (22\%) e Massas Polares Velhas (14\%) descaracterizadas pelo aquecimento basal devido a maior incidência solar nessa época do ano no Hemisfério Sul, ainda verificou-se que em $13,5 \%$ dos dias dos meses referentes à estação do ano Santa Maria esteve sob domínio de Frentes Polares Atlânticas, como demonstra a figura 04:

No Verão 2011/2012 é possível observar uma maior

Tabela 07. Precipitação total dos verões 2010/2011, 2011/2012 e 2012/2013.

\begin{tabular}{cc}
\hline Verão & Precipitação \\
\hline $2010 / 2011$ & $311,9 \mathrm{~mm}$ \\
\hline $2011 / 2012$ & $346,7 \mathrm{~mm}$ \\
\hline $2012 / 2013$ & $560,4 \mathrm{~mm}$ \\
\hline
\end{tabular}

Fonte: Jornal "A Razão"

Org.: Weber, A. A., 2013 


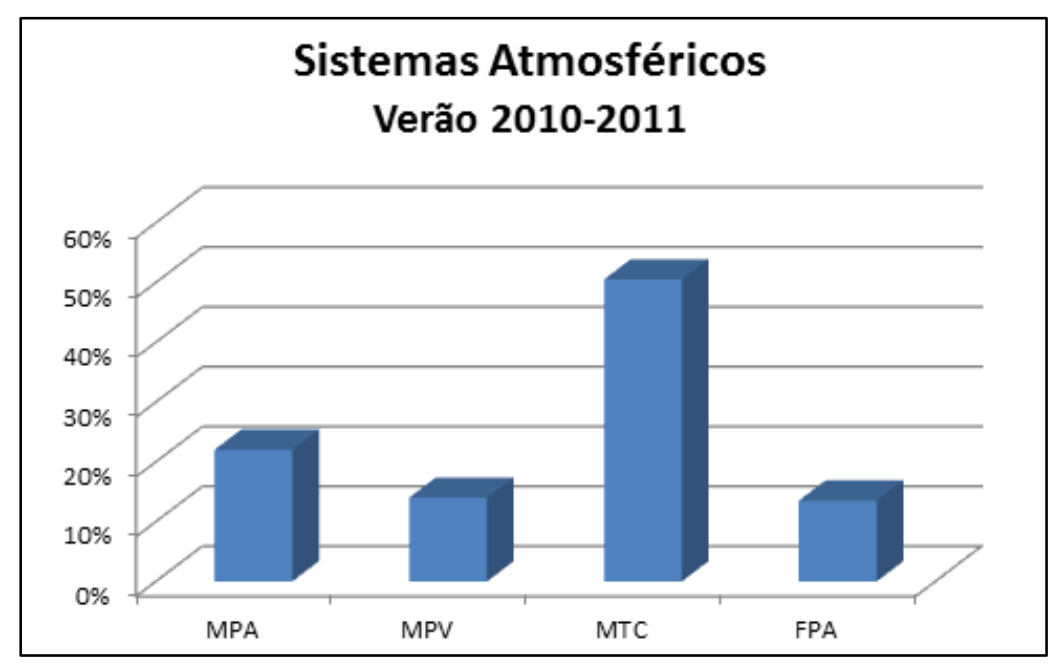

Figura 04. Sistemas Atmosféricos atuantes no verão 2010/2011 em Santa Maria - RS Org.: Weber, A. A., 2013

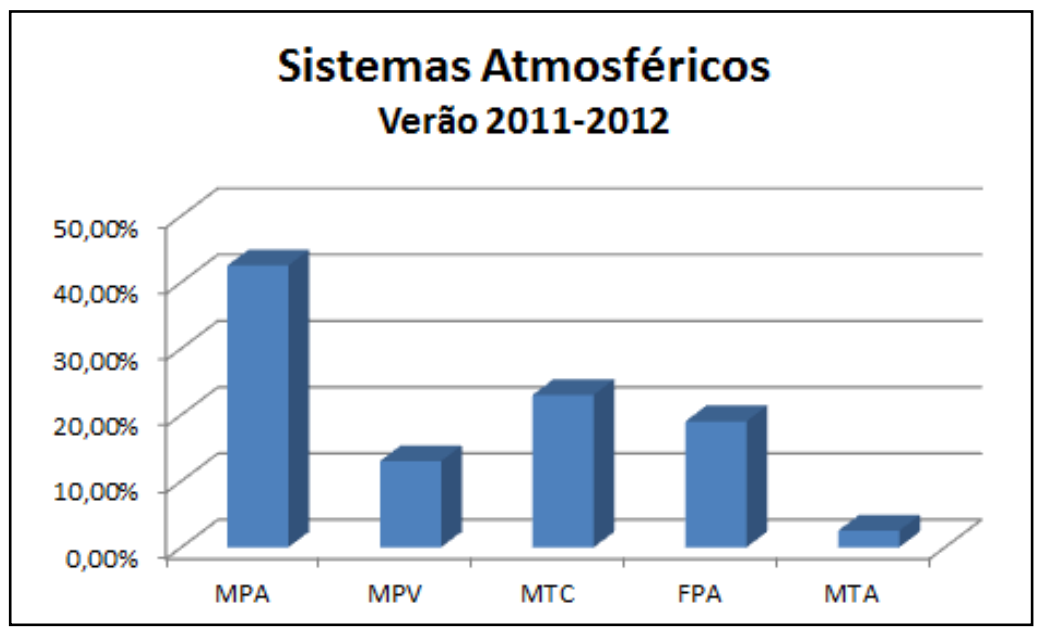

Figura 05. Sistemas Atmosféricos atuantes no verão 2011/2012 em Santa Maria - RS Org.: Weber, A. A., 2013

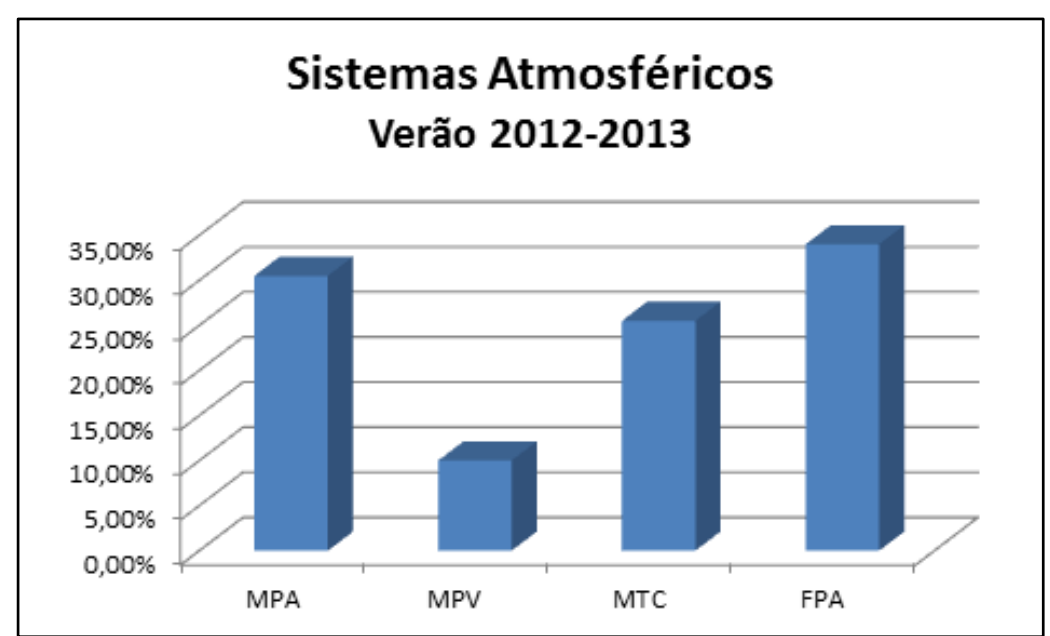

Figura 06. Sistemas Atmosféricos atuantes no verão 2012/2013 em Santa Maria - RS Org.: Weber, A. A., 2013 
incidência das Massas de ar de origem polar, atuando em $42,5 \%$ dos dias, assim como as massas polares velhas $13 \%$, é possível perceber também que em 19\% dos dias a cidade esteve sob influência de alguma Frente Fria. As massas de ar de origem tropical, sendo elas continentalizadas ou atlântica predominaram $23 \%$ e 2,5\% respectivamente, como demonstra a figura 05:

A participação de 34\% de Frentes Polares Atlânticas no verão 2012-2013 explica o fato de esse verão ter tido um total pluviométrico de cerca de $460 \mathrm{~mm}$, a participação de massas polares foi de 30,5\% e de Massa Polar Velha foi de $10 \%$ do total de dias, as massas tropicais tiveram uma participação de 25,5\% (figura 06).

\section{A influência climática sobre os incêndios residenciais}

Dos 28 incêndios registrados nos anos apurados, 19 se configuraram como incêndios residenciais, nesta parte do trabalho serão feito, então, um cruzamento entre os incêndios residenciais e os sistemas atmosféricos atuantes nos dias dos sinistros. Deste modo serão utilizados somente dados de incêndios residenciais.

Nos três verões analisados foi possível observar que em $52 \%$ dos casos de incêndios ocorridos o sistema atmosférico atuante se tratava da Massa tropical continental com o tipo de tempo Depressionário Continental que segundo Sartori (2003) resulta da expansão da Massa
Tropical Continental, devido ao aprofundamento da Depressão do Chaco, que eventualmente atinge o Rio Grande do Sul. Esse tipo de tempo é dos mais característicos no verão, quando as temperaturas máximas atingem quase sempre $35^{\circ} \mathrm{C}$.

Em 21\% dos casos analisados o sistema atmosférico atuante se tratava da Massa Polar Atlântica, pode se notar que esses casos aconteceram, principalmente nos meses de março, quando essas massas retornam com mais intensidade ao Rio Grande do Sul devido à proximidade do outono e o movimento natural da Terra que faz com que a região receba menos radiação solar.

Ocorreu apenas um incêndio residencial sob influência da Massa polar velha, enquanto os incêndios ocorridos nos dias de domínio das frentes polares atlânticas chegaram a $21 \%$ do total como demonstra a tabela 08 .

\subsection{Verão 2010/2011}

No verão de 2010/2011 ocorreram apenas dois incêndios, um em fevereiro e outro em março, sendo os dois sob domínio de massas polares, mesmo uma descaracterizada pelo aquecimento basal. A Tabela 09 demonstra o dia do acontecimento do incêndio e o sistema atmosférico atuante.

A figura 07 demonstra as condições do tempo atmosférico no mês e no dia do acontecimento do incêndio, o ponto vermelho no gráfico demonstra o dia do incêndio:

Tabela 08: Incêndios x sistemas atmosféricos atuantes

\begin{tabular}{ccc}
\hline $\begin{array}{c}\text { Sistemas atmosféricos } \\
\text { atuantes }\end{array}$ & $\begin{array}{c}\text { Total de incêndios resi- } \\
\text { denciais }\end{array}$ & $\mathbf{\%}$ \\
\hline MTC & 10 & 52,7 \\
\hline MPA & 4 & 21 \\
\hline MPV & 1 & 5,3 \\
\hline FPA & 4 & 21 \\
\hline Total & $\mathbf{1 9}$ & $\mathbf{1 0 0}$ \\
\hline
\end{tabular}

Org.: Weber, A. A., 2013

Tabela 09: Incêndios x sistemas atmosféricos atuantes verão 2010/2011

\begin{tabular}{cc}
\hline Data & Sistema Atmosférico \\
\hline $02 / 02 / 2011$ & MPA \\
\hline $23 / 03 / 2011$ & MPV \\
\hline
\end{tabular}

Org.: Weber, A. A., 2013 

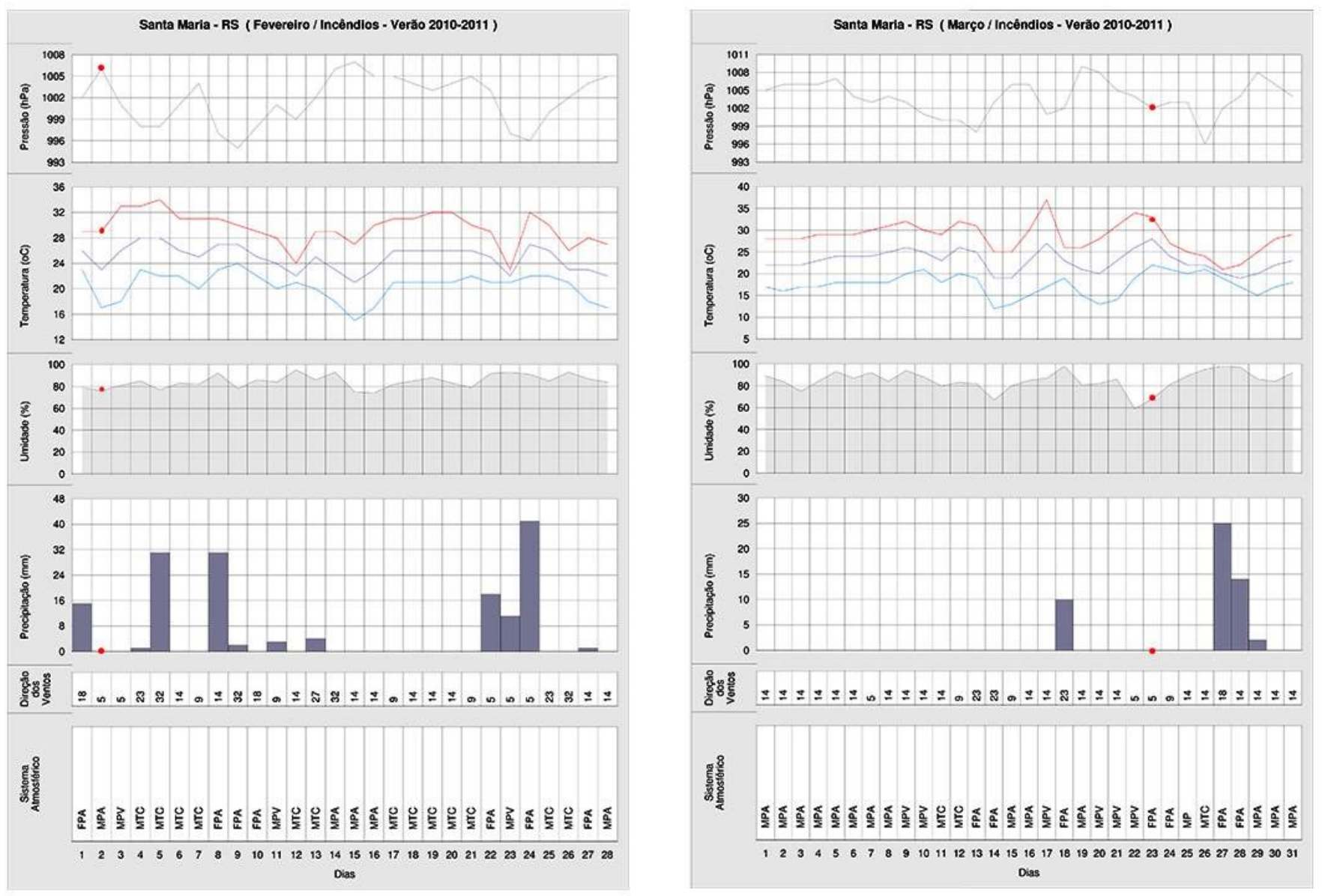

Figura 07: Incêndios x Sistemas Atmosféricos atuantes no verão 2010/2011 Org.: Weber, A. A., 2013

O incêndio do dia 02/02 estava sob influência da Massa polar atlântica, sob o Tempo Anticiclonal Aquecido, que segundo Sartori (2003) é uma variação do Tempo Anticiclonal Típico, motivado pelo aquecimento do ar de origem polar sobre o continente nas latitudes subtropicais e tropicais e consequente enfraquecimento do APA. Já o incêndio do dia 23/03 estava sob domínio da frente polar atlântica sob o Tempo Frontal de Sudoeste de Fraca Atuação

\subsection{Verão 2011/2012}

O verão 2011/2012 caracterizou-se por uma forte atuação das Massas Tropicais Continentais que atuaram em cerca de $50 \%$ dos dias, essa estação se caracterizou por fortes ondas de calor, principalmente nos meses de dezembro e janeiro. Esta estação registrou 14 incêndios residências em todos os quatro meses. A Tabela 10 demonstra os dias dos incêndios e os sistemas atuantes.

Os pontos vermelhos na figura 08 demonstram os incêndios ocorridos no verão 2011/2012 e os sistemas atmosféricos atuantes nos respectivos dias, assim como as condições de tempo atmosférico:

Podemos perceber claramente a relação entre os incêndios ocorridos neste verão com o domínio das
Massas tropicais continentalizadas, em 64, 3\% dos casos, os incêndios ocorridos sob domínio das massas polares contabilizaram $21,4 \%$ dos casos e as frentes $14,3 \%$, a tabela 11 identifica a situação.

Os incêndios ocorridos sob a Massa Tropical Continental, em grande parte estão associadas à condição de Tempo Depressionário Continental, que de acordo com Sartori (2003) esse tipo de tempo é um dos mais característicos do verão gaúcho, tendo as temperaturas máximas quase sempre superiores a $35^{\circ} \mathrm{C}$, com pressão atmosférica muito baixa. Então com as temperaturas mais elevadas a susceptibilidade da ocorrência de incêndios é maior, devido a uma maior utilização de sistemas de resfriamento, como ar-condicionado e ventiladores, geram uma sobrecarga nos sistemas elétricos residenciais. O baixo índice de umidade relativa do ar, assim como uma maior exposição à radiação solar também estão intimamente ligados a esse fenômeno.

Os três casos de incêndios relacionados a massas polares, assim como os influenciados pelas frentes polares, estão associados ao mês de março, onde nessa estação, as massas polares voltaram a agir com mais força, devido à proximidade com o outono, associadas, principalmente ao Tempo Anticiclônico Polar Pós-Frontal e ao Tempo Anticiclônico Polar Marítimo. 
Tabela 10. Incêndios x sistemas atmosféricos atuantes no verão 2011/2012

\begin{tabular}{cc}
\hline Data do Incêndio & Sistema Atmosférico \\
\hline $02 / 12 / 2011$ & MTC \\
\hline $17 / 12 / 2011$ & MTC \\
\hline $17 / 12 / 2011$ & MTC \\
\hline $26 / 12 / 2011$ & MTC \\
\hline $30 / 12 / 2011$ & MTC \\
\hline $31 / 12 / 2011$ & MTC \\
\hline $19 / 01 / 2012$ & MTC \\
\hline $26 / 01 / 2012$ & MTC \\
\hline $07 / 02 / 2012$ & MTC \\
\hline $24 / 02 / 2012$ & FPA \\
\hline $06 / 03 / 2012$ & MPA \\
\hline $19 / 03 / 2012$ & MPA \\
\hline $24 / 03 / 2012$ & FPA \\
\hline $29 / 03 / 2012$ & MPA
\end{tabular}

Org.: Weber, A. A., 2013

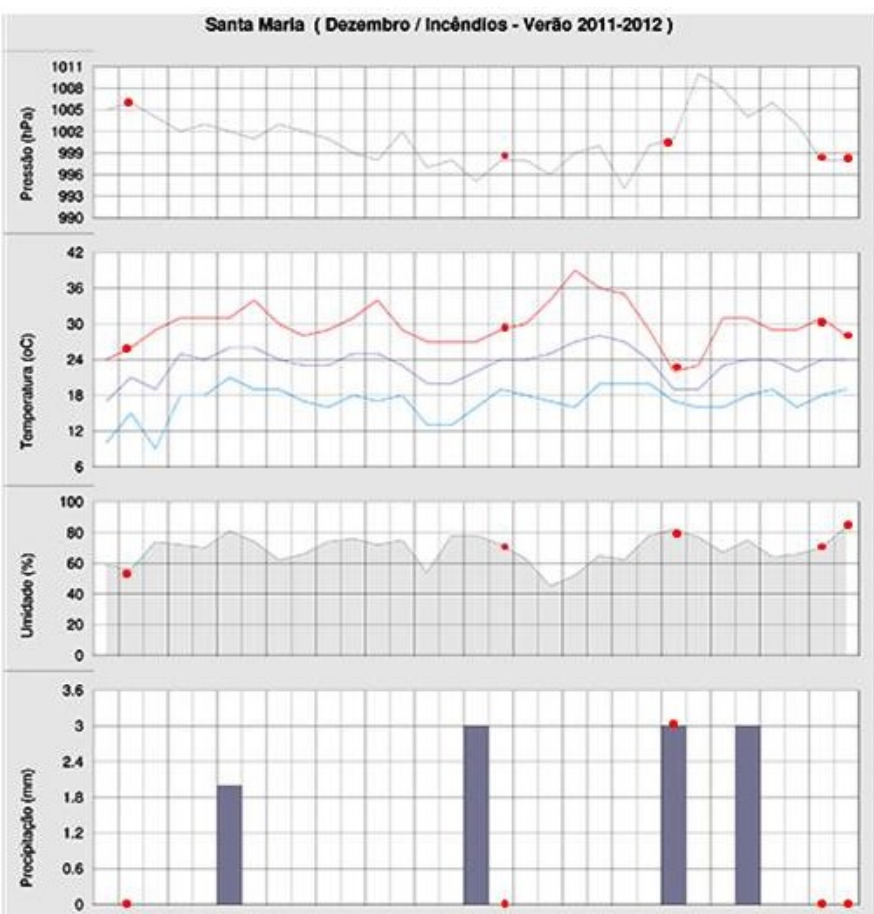

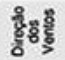

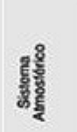

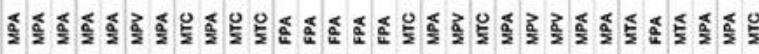

123456 F $3910111213141516171819202122 \quad 232425262728293031$ Das

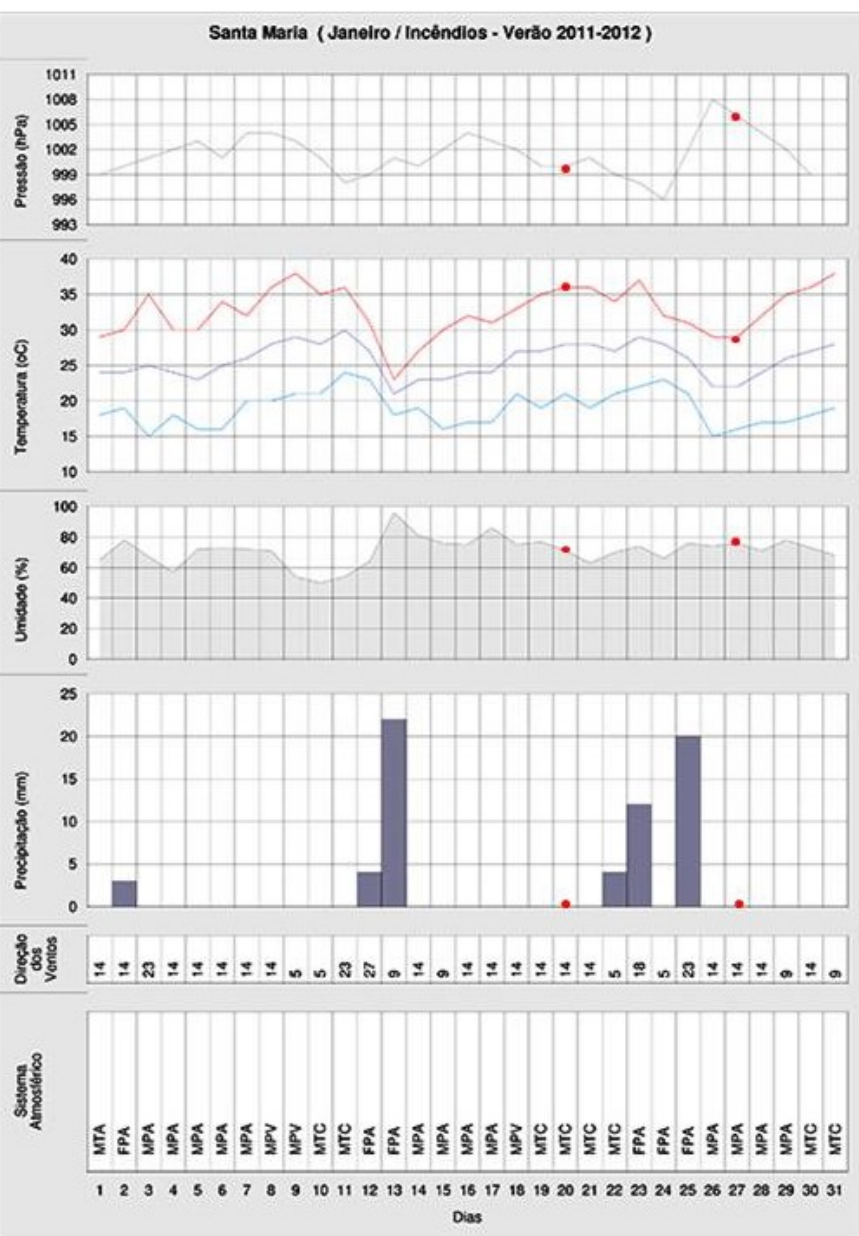

Continua...

Figura 08: Incêndios x Sistemas Atmosféricos atuantes no verão 2011/2012 


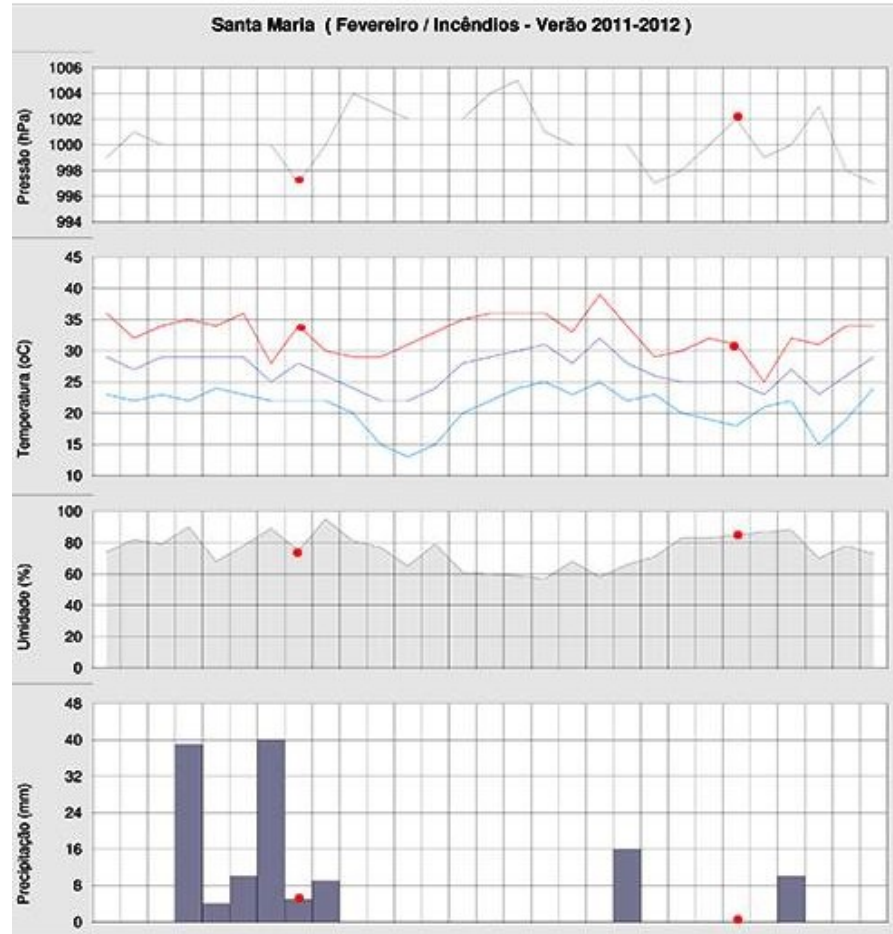

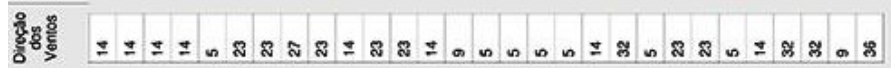

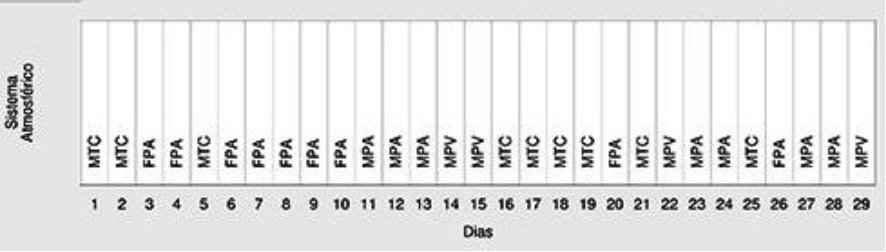

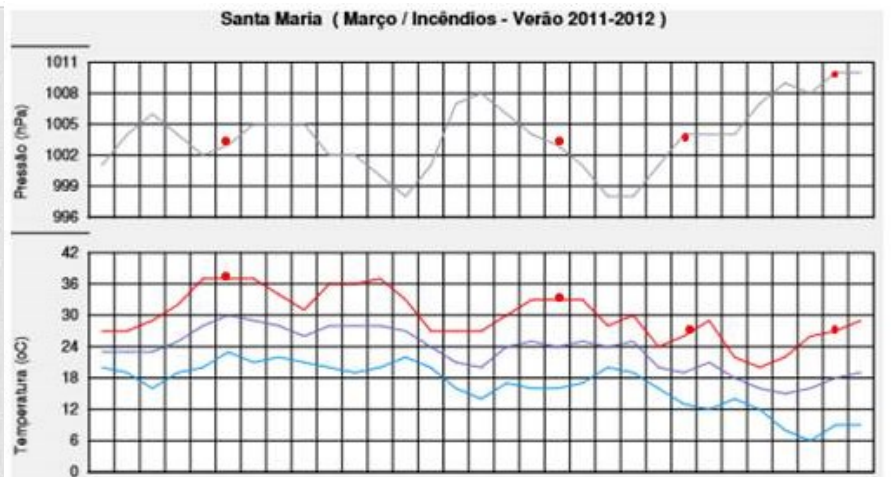
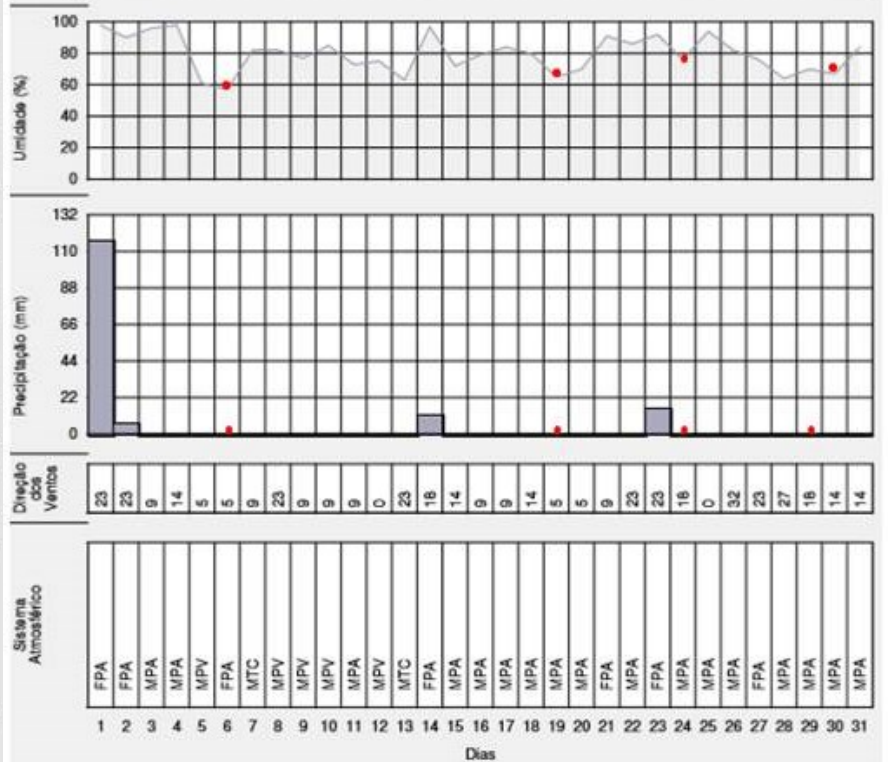

Figura 08: Continuação...

Tabela 11. Porcentagem de incêndios x sistemas atmosféricos atuantes no verão 2011/2012

\begin{tabular}{ccc}
\hline $\begin{array}{c}\text { Sistemas atmosfé- } \\
\text { ricos atuantes }\end{array}$ & $\begin{array}{c}\text { Total de incêndios resi- } \\
\text { denciais }\end{array}$ & $\mathbf{\%}$ \\
\hline MTC & 9 & 64,3 \\
\hline MPA & 3 & 21,4 \\
\hline FPA & 2 & 14,3 \\
\hline Total & $\mathbf{1 4}$ & $\mathbf{1 0 0}$ \\
\hline
\end{tabular}

Org.: Weber, A. A., 2013 


\subsection{Verão 2012/2013}

Por último, no verão 2012/2013, constataram-se apenas três incêndios, nos meses de dezembro, janeiro e fevereiro, um em cada mês, sendo dois sob a atuação de frentes polares e um sob domínio da Massa tropical continental, conforme demonstra a tabela 12.

A figura 09 demonstra, a partir dos pontos vermelhos, os dias em que se registraram casos de incêndios na cidade de Santa Maria e as condições de tempo, assim como os sistemas atmosféricos atuantes:
O verão 2012/2013 registrou um intenso domínio das Frentes polares, muito se deve a isso os altos totais de pluviometria, que passaram os $450 \mathrm{~mm}$. Desta maneira os incêndios dos dias 28/12/2012 e 03/202/2013 aconteceram sob influência deste sistema. Nos dois casos registraram-se precipitações e temperaturas máximas entre 25 e $30^{\circ} \mathrm{C}$, além de altos índices de umidade relativa do ar, condizentes com o Tempo Frontal de Sudoeste de Atuação Moderada, que Sartori (2003) afirma serem provocados pela passagem normal da FPA, sem estacionar sobre o estado, originando densa nebulo-

Tabela 12. Incêndios x sistemas atmosféricos atuantes no verão 2012/2013

\begin{tabular}{cc}
\hline Data & Sistema Atmosférico \\
\hline $28 / 12 / 2012$ & FPA \\
\hline $24 / 01 / 2013$ & MTC \\
\hline $03 / 02 / 2013$ & FPA \\
\hline
\end{tabular}

Org.: Weber, A. A., 2013
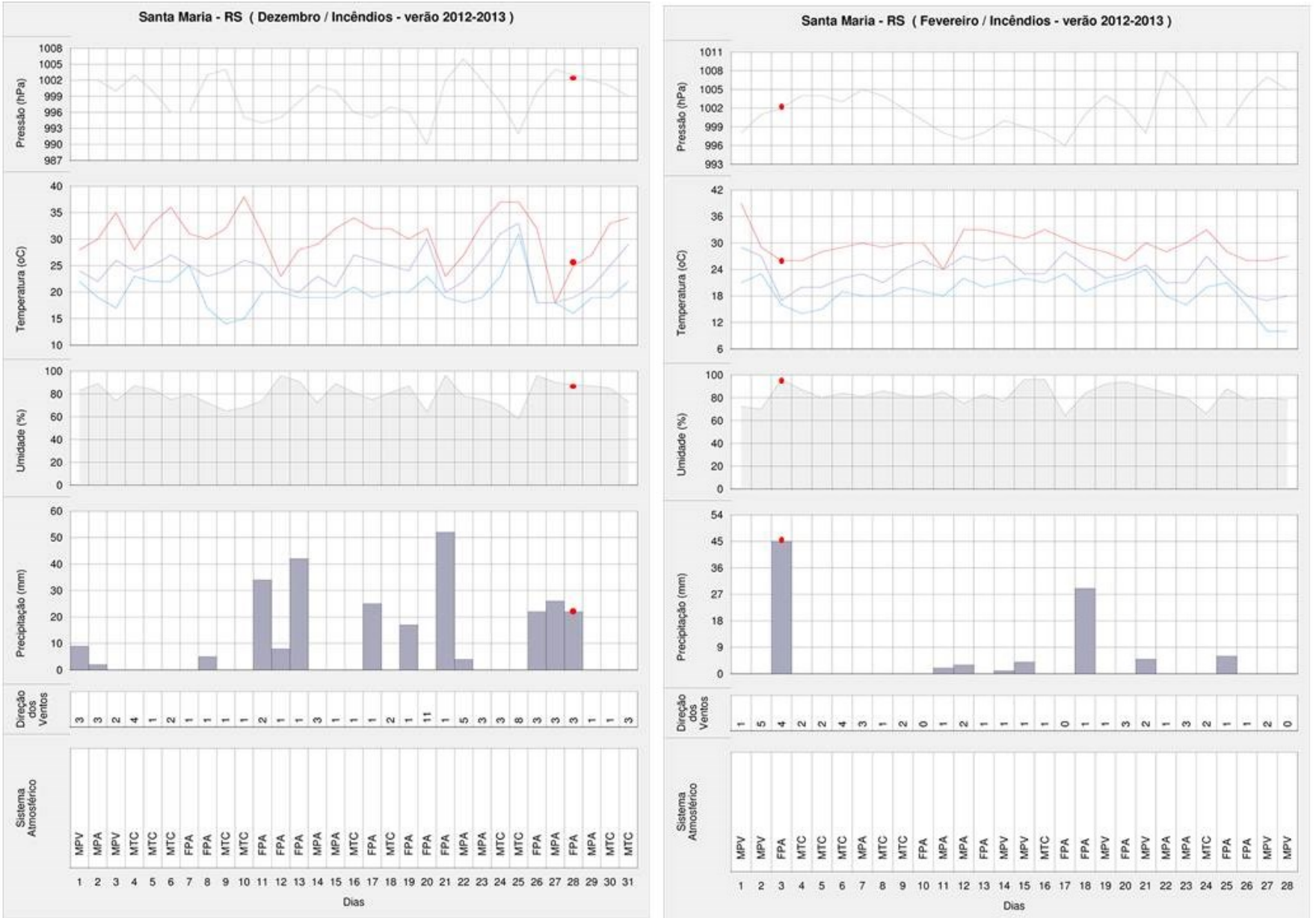

Figura 09: Incêndios x Sistemas Atmosféricos atuantes no verão 2011/2012

Org.: Weber, A. A., 2013

Continua... 


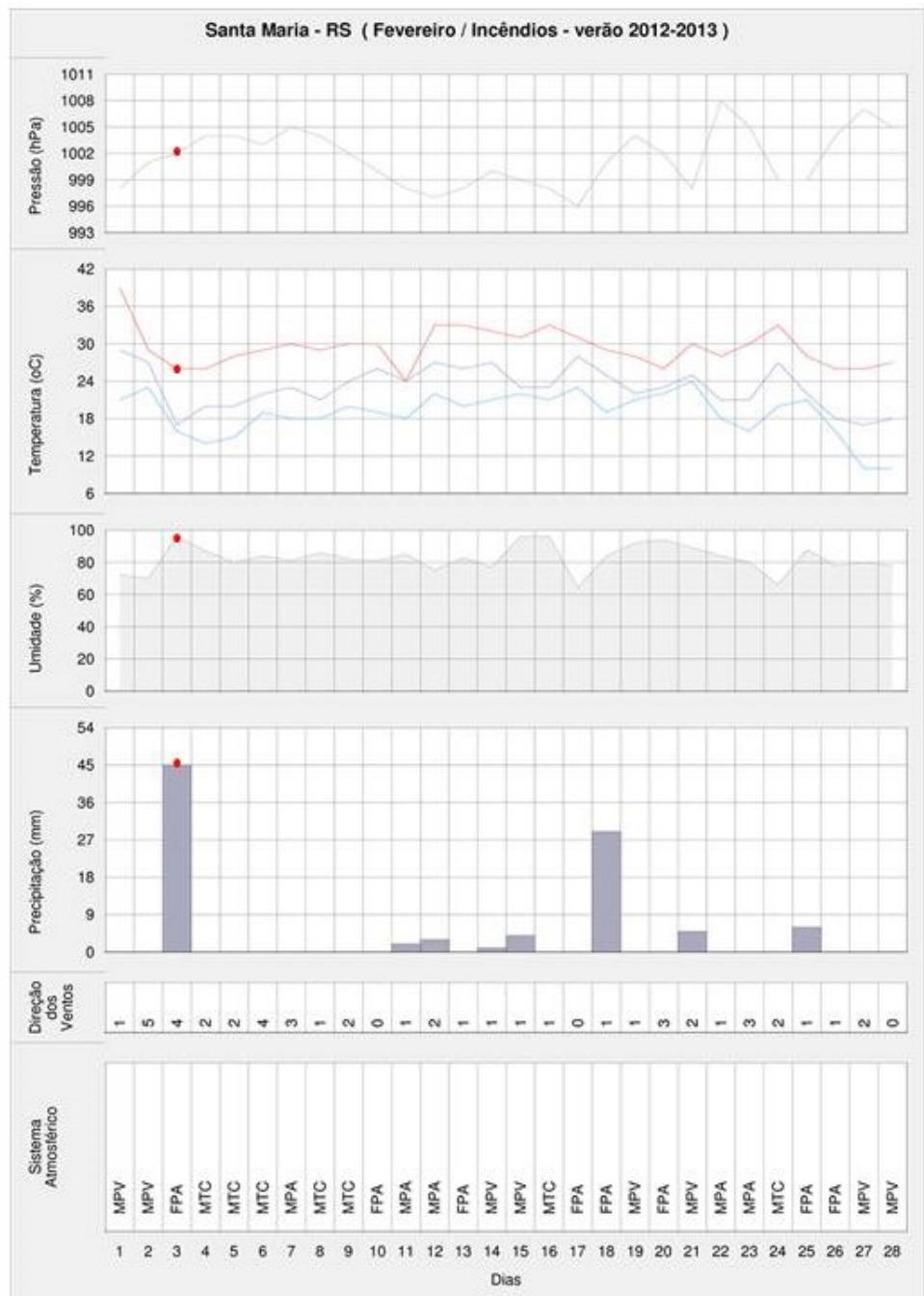

Figura 09: continuação...

sidade e chuvas de volume razoável (> $50 \mathrm{~mm}$ ), com relâmpagos e trovoadas, provocadas tanto por nuvens estratiformes (nimbos-estratos) quanto cumuliformes (cúmulos-nimbus), após fase pré-frontal bem definida, com ventos do quadrante norte. A autora ainda coloca que em determinadas épocas do ano essa condição de tempo é responsável por provocar temporais com chuvas fortes e queda de granizo.

O incêndio ocorrido no dia 24/01/2013 estava associado a uma Massa tropica continental, neste dia registrou-se uma temperatura máxima superior a $35^{\circ} \mathrm{C}$, além de baixa umidade do ar, assim com baixas pressões atmosféricas, certamente associadas ao Tempo Depressionário Continental.

\section{Considerações Finais}

Com a presente pesquisa constatou-se a ligação entre os incêndios residenciais urbanos e os fatores climáticos, principalmente sob o domínio das Massas Tropicais continentais, onde $52,6 \%$ dos casos estavam ligados a esse domínio, que tem por característica apresentar um tempo quente e seco. O verão de 2011/2012 apresentou um maior numero de incêndios e uma maior frequência deste tipo de domínio, neste caso foi possível atrelar os fatores climáticos à ocorrência de incêndios, já nos outros verões não foi possível encontrar uma grande relação entre os dois fatores.

O conhecimento desses fatores torna-se de grande importância no contexto atual, onde se busca uma melhora na qualidade e preservação da vida da população em geral. Todavia, salienta-se que além do ritmo climático envolvido nos incêndios residenciais, outros aspectos observados são que grande parte dos sinistros, deu-se em bairros onde as condições econômicas são baixas. 


\section{Referências}

AYOADE, J.O. Introdução à climatologia para os Trópicos. $3^{\circ}$ ed. São Paulo: Bertrand Brasil, 1991.

COSTA, E. R. O campo termo-higrotérmico intra-urbano e a formação de ilhas de calor e frescor urbanas em Santa Maria - RS. 2009. 117 f. Dissertação (Mestrado em Geografia) Universidade Federal de Santa Maria, 2009.

EMPRESA DE PESQUISA ENERGÉTICA - EPE. Consumo Final e Conservação de Energia Elétrica: 1970 - 2005. Rio de Janeiro: EPE, 2006.

\section{INSTITUTO BRASILEIRO DE GEOGRAFIA} E ESTATÍSTICA (IBGE). Cidades. 2010. Disponívelem:<http://cidades.ibge.gov.br/painel/ painel. php?lang=\&codmun $=431690 \&$ search $=r$ io-grande-do-sul | santa-maria I infograficos:-dadosgerais-do-municipio>. Acesso em: 19 Fev. 2014.

NIMER, E. Climatologia do Brasil. Rio de Janeiro: IBGE, 1989.

MENDONÇA, F. Clima e Criminalidade: Ensaio analítico da correlação entre temperatura do ar e a incidência de criminalidade urbana. Curitiba: Editora UFPR, 2002.

MONTEIRO, C. A. F. Clima e excepcionalismo: conjecturas sobre o desempenho da atmosfera como fenômeno geográfico. Florianópolis: UFSC. 1990. 241p.

MONTEIRO, C. A. F. Análise Rítmica em Climatologia: problemas da atualidade climática em São Paulo e achegas para um programa de trabalho. São Paulo: Universidade de São Paulo/ Instituto de Geografia, 1971. 21 p.

MONTEIRO, C. A. F. Geografia do Brasil: Grande Região Sul. Rio de Janeiro: IBGE, 1963.

MONTEIRO, C. A. F. Sobre um Índice de Participação das Massas de Ar e suas Possibilidades de Aplicação à Classificação Climática. Revista Geográfica. Rio de Janeiro, v. 33, n. 61, p. 59-69, 1964.

SARTORI, M. G. B. Clima e Percepção. Universidade de São Paulo, vol. 2, 2000.

SARTORI, M. G. B. A dinâmica do clima do Rio Grande do Sul: indução empírica e conhecimento científico. Revista Terra Livre, São Paulo, v. 1, n. 20, p. 27-49, 2003.
SARTORI, M. G. B. A circulação atmosférica regional e os principais tipos de sucessão do tempo no inverno do Rio Grande do Sul, Brasil. Ciência e Natura, n. 15, p. 69-93, 1993.

SARTORI, M. G. B. A circulação atmosférica regional e as famílias de tipos de tempo identificadas na região central do Rio Grande do Sul. Ciência e Natura, n. 3, p. 101-110, 1981.

SARTORI, M. G. B. Frequência sazonário da participação dos sistemas atmosféricos em 1973, na região de Santa Maria, RS. Ciência e Natura, n. 2, p. 41-53, 1980.

WOLLMANN, C. A. A gênese climática das enchentes na Bacia Hidrográfica do Rio Caí. 2008. 115p. Trabalho de Graduação (Graduação em Geografia Bacharelado) - Universidade Federal de Santa Maria, 2008.

WOLLMANN, C. A. O clima do Rio Grande do Sul no Verão: Análise sobre a circulação atmosférica regional e os principais tipos de sucessão do tempo em três casos típicos. Geografia, Ensino e Pesquisa, v 13, p. $33-43.2009$.

WOLLMANN, C. A. Frequência mensal e sazonal da participação de sistemas atmosféricos no verão do Rio Grande do Sul: análise sobre três casos típicos (1986/1987, 1997/1998 e 2004/2005). Ciência e Natura, v 31, p. 141 - 161. 2009.

WOLLMANN, C. A. Sazonalidade dos episódios de enchentes ocorridos na bacia hidrográfica do Rio Caí, e sua relação com o fenômeno El niño, no período de 1982 a 2005. Revista Brasileira de climatologia, ano 6., v 7, p.103-118, 2010. 